\title{
Japanese University Students’ Attitudes towards Globalisation, Intercultural Contexts and English
}

\author{
Liang Morita ${ }^{1, *}$ \\ ${ }^{1}$ Graduate School of Languages and Cultures, Nagoya University, Nagoya, Japan \\ *Correspondence: Graduate School of Languages and Cultures, Nagoya University, Furo-cho, Chikusa-ku, Nagoya \\ 464-8601, Japan. liang@lang.nagoya-u.ac.jp
}

Received: October 10, 2013 Accepted: October 20, 2013 Online Published: December 17, 2013

doi:10.5430/wjel.v3n4p31 URL: http://dx.doi.org/10.5430/wjel.v3n4p31

This is a study conducted at Nagoya University, a top Japanese national institution, on undergraduates' attitudes towards globalisation, intercultural contexts and English. Globalisation takes place in a varied context in Japan which includes the sakoku (closed country) mentality as well as government rhetoric encouraging all to embrace globalisation. According to the literature on internationalisation of higher education, intercultural contexts result from globalisation and educators must prepare students to function in these contexts. Students, however, may or may not see the future in the same way educators and policy-makers do. Attitudes towards English are mixed: some see it as an indispensable communicative tool for the future while others think of it as a test score which helps them secure jobs or places in graduate programmes. The author discovered in this study that while most of the students' attitudes echo government rhetoric, they think globalisation is something they can opt out of. In addition, even though they feel that the ability to function in intercultural contexts is desirable, half of them do not think they will find themselves in these contexts, which may compromise the effectiveness of curriculum which have been planned based on the assumption that students are going to be in intercultural contexts in future. They are also protective of Japanese culture and very concerned about their English communicative skills.

Keywords: attitude; globalisation; intercultural context; internationaliation

\section{Introduction}

This paper is part of a continuing inquiry into Japanese university students' attitudes towards English, globalisation and internationalisation. In an earlier work (Morita, 2013) based on a smaller sample ( $\mathrm{n}=55)$, the author found that although most students (81.5\%) agreed it was important to be able to function in intercultural contexts in principle, fewer (53.7\%) wanted the ability and fewer (50\%) still thought they would be in such contexts. Comments in the data indicated that some students felt that being in intercultural contexts was a matter of choice and they existed outside one's national boundaries. Others thought that globalisation was a process which took place elsewhere and did not apply to them. These comments hint at a lack of interest in being part of the global community. Concerning the role of English, some respondents felt that English would be useful in entrance examinations for graduate school or job applications while others thought they had a real need to communicate in English. This paper probes into the above issues with the help of a large sample ( $\mathrm{n}=109)$.

In recent years, the globalisation of commerce, social forces, idea exchange and growth in student mobility have been driving the internationalisation of higher education. (Hudzik, 2011) Hudzik defines globalisation as the rise of factors and forces that transcend borders and sovereign states. Globalisation describes the breaking down of local, regional and national boundaries in economic action, scientific discourse and cultural patterns, among others (Weber, 2001). Internationalisation is a manifestation of the phenomenon of globalisation. Internationalisation of higher education is one of the ways in which a country responds to the impact of globalisation. (Knight, 1999) Globalisation has transformed higher education throughout the world, propelling local institutions, their staff, students and graduates irreversibly into the world-wide environment. (Marginson, 2003) In a globalised world, those who were once far away are now our neighbours. (Featherstone, 1990) In such a world, intercultural competence or intercultural literacy is an important graduate outcome. Intercultural competence refers to the understandings, competencies, attitudes, language proficiencies, participation and identities necessary for successful cross-cultural 
engagement. (Heyward, 2002) One of the goals or objectives of internationalisation is to give students intercultural competence. A major aspect of the internationalisation of higher education is to prepare staff, faculty and students to function in intercultural contexts, or in Byram's (2011) words, 'to learn to live together'. In non-English-speaking countries such as Japan, this includes proficiency in English, since second- or third-language proficiency is important to intercultural competence. (Turner \& Robson, 2008)

A common rationale for learning English in Japan is that English is the most important international language of business, science and technology, and that English is essential for participation in the global economy. (Yamagami \& Tollefson, 2011) The learning of English has been a major thrust of the government's push for greater internationalisation of Japanese society since the 1980s. Policy documents and discussion papers have focused on the need for the Japanese to learn to speak English better and more widely. (Gottlieb, 2005) The role of English as an international language is emphasised:

'With the progress of globalization in the economy and in society, it is essential that our children acquire communication skills in English, which has become a common international language, in order for living in the $21^{\text {st }}$ century. This has become an extremely important issue both in terms of the future of our children and the future development of Japan as a nation.'

(MEXT, 2002)

Implicit in the quotation above is the assumption that Japanese children will be using English in living with the rest of the world and the ability to do so is presented as very important both to the children and the country. The above justification for learning English is also common in many countries such as Singapore and Korea. However, in Japan, there are alternative views on globalisation and the role of English.

In a recent article in the Japan Times, Burgess (2013) wrote about the country's ambivalent attitude towards globalisation. On the one hand, Japan is aware that in order to remain economically competitive, it must open up, instigate reforms and embrace globalisation in all its aspects. On the other hand, there is still a strong tendency to close in, reject global norms and standards, and retreat inwards. Burgess concludes that both government and society are inward-looking and remain rooted in an insular world view that sees globalisation as an external process which is owned by somebody else.

Yamagami and Tollefson (2011) also found an ambivalence towards globalisation in Japan. Globalisation is perceived as an opportunity as well as a threat. In many instances in which globalisation is represented as an opportunity, the government emphasises that both individuals and the nation must develop new skills (especially in technology and English) in order to meet the challenges. On the other hand, Diet (parliament) discourse articulates the threats that globalisation presents: violent crime, reduced personal and national security, and a sense of loss and uncertainty about the future. This shows that not everyone in Japan is eager to embrace globalisation.

Some researchers have written about Japan's unwillingness to open up to the world. Itoh (2000) explained the attitude by citing sakoku, the 250 years of self-imposed isolation from the rest of the world which took place from 1639 to 1868. She claims that the pervasive Japanese attitude of exclusiveness and parochialism stems from two powerful roots: the country's geographic isolation as an island nation and the history of sakoku. Itoh believes that the sakoku mentality still influences the way the Japanese think, behave and relate to the world. Although the country's manufacturers are keen to flood the world with their products, the ubiquity of Japanese goods is not matched by the presence of Japanese working for the world. Traditional characteristics of insularity and parochialism are still preserved and the sakoku mentality still lingers and underlies modern Japanese ways of thinking and behaving.

Dougill (1995) discussed the history of insularity and argued that the Japanese have no real interest in integrating with the international community due to a deeply ingrained form of cultural conditioning. Both Clammer (2001) and Itoh (2000) pointed out a lack of interaction with the international community. Clammer claims that Japanese society does not reward individuals who put the rhetoric of internationalisation into practice. Examples are Japanese graduates of foreign universities who are discriminated against when seeking employment and company employees who resist being posted overseas because they will be left out of the inner political circles in the organisation.

Burgess (2013) also supports the above view about Japanese companies. Although some high-profile Japanese companies such as Rakuten are exceptions, Japanese hierarchical corporate culture can be uncomfortable with confident and outspoken returnee students. A number of Japanese with study-abroad experience found Japanese companies unenthusiastic and reluctant to hire them. In a survey of 1,000 companies on their recruitment plans for the fiscal year 2012, less than a quarter said they planned to hire applicants who had studied abroad.

Unlike in Singapore, where an overwhelming majority embraces English, there are conflicting attitudes towards 
English in Japan. (Kubota, 1998) On the one hand, there is a trend towards internationalisation in government and business, which stresses learning English as a means of making Japan more international. On the other hand, nihonjinron or theories of being Japanese, an ideology which 'attempts to define a distinct Japanese cultural and linguistic identity vis-à-vis the Western culture and language: particularly English.' (Kubota, 1998: 299) This view, which emphasises the cultural uniqueness of Japan and linguistic uniqueness of Japanese, does not encourage the teaching and use of English, and some even see it as a form of colonisation. They fear that the spread and use of a foreign language could diminish the role of the national language and threaten Japan's distinctive culture. Although some researchers believe that the nihonjinron movement of the 1970s is dated and has little impact anymore, and its supporters are no longer taken very seriously in academic circles, it seems that there are still some who subscribe to the idea.

In addition to supporters of nihonjinron, some Japanese are sceptical about English for other reasons such as linguistic sovereignty and equality. Suzuki Takao, a professor emeritus of linguistics, strongly believes that Japan should defend its linguistic sovereignty. (Suzuki, 1999) He argues that when high-level Japanese politicians converse with their international counterparts in English instead of in Japanese through interpreters, they cede power to the English camp rather than defend the linguistic equality of the Japanese. He takes a firm stance in favour of retaining a clearly separate linguistic identity rather than follow the trend to use English in the international community. Another scholar, Inoguchi Takashi, although disagreeing with Suzuki on linguistic sovereignty, feels it would be a much better strategy to limit English education to those planning to become high-ranking officials in the civil service instead of teaching English to all students. He believes that all Japan needs is a core of really fluent English speakers for external interactions. (Gottlieb, 2005) International communication specialist Tsuda Yukio $(1990,1996)$ saw the dominance of English as something to be resisted. He emphasised the principle of equality in communication and proposed the establishment of international communication treaties to guarantee the use of one's mother tongue at international conferences.

The fact that researchers and the government see the future as an intercultural environment which requires the use of English does not necessarily mean that university students share the perception. The literature on alternative views on globalisation cited earlier suggests that students may have varied attitudes towards globalisation. If a major aspect of the internationaliation of higher education is to prepare students to function in intercultural contexts, in order to succeed, students have to be able to see themselves in intercultural contexts as a likely scenario. Although there are many studies, government documents and media reports emphasising the importance of intercultural competence and English, there are few studies which investigate students' attitudes towards the future and English. One of them is Whitsed and Wright 2011. The English teachers in the study reported that the vast majority of non-language major undergraduates are not convinced by the MEXT rhetoric that all students need communicative English skills. The idea that English is indispensible in the international market is not supported in their experience. Many believe that they will have no real use for English in their future.

Within Japan, English plays a limited role in everyday life. A small number of Japanese use English in work-related correspondence and some professionals in science-related fields read in English. (Yano, 2001) Despite the strong presence in advertising, pop culture and the media, very few people use English to interact with others. The vast majority of Japanese people do not need to use English in their daily lives. (Seargeant, 2009)

As far as university students are concerned, English is mostly a tool for gaining admission to universities. For most students, the sole motivation in learning English was to pass university entrance examinations, and after they have achieved that goal, they have no purpose or interest in learning English anymore. (Matsuda, 2011) While it is true that English competency measured by tests such as the Test of English for International Communication (TOEIC) is used as a means of screening for employment and promotion in some corporations, in most places of employment, English is not a prerequisite for finding stable work and decent wages. (Seargeant, 2009) Even employees who have secured their positions with outstanding TOEIC scores often do not require English at work. (Morita, 2010) Kubota's (2011) study indicated that the need for English in the workplace might be overestimated. Executives of manufacturing companies that have factories and/or offices abroad reported that an average of $9.5 \%$ of employees write emails in English regularly. In job advertisements at the Employment Security Bureau in October 2007, only $1.4 \%$ of jobs in Tokyo required English skills. Kubota concluded that there is a gap between the discourse that elevates the usefulness of English and the actual demands. Tsuchiya (2004) found that some university students sensed that English was useless and that affected their motivation to learn the language.

The sociolinguistic context of English is very different from that of the Philippines or India, where learners enjoy significant employment advantages from English due to wage differentials from the developed world. Tens of 
thousands of Filipinos are employed in the US\$1.7 billion medical transcription industry, transcribing paper medical files from the US and entering them into electronic databases. In India, employees in call centres also benefit from their English abilities in the US\$2.7 billion industry. In Japan, only a small number of learners from privileged backgrounds benefit from their English skills. They include employees in international companies, international organisations such as the United Nations, some non-governmental organisations and students who attend universities outside Japan. (Yamagami \& Tollefson, 2011)

Another interesting aspect of English in Japan is that it is linked to the idea of national development, including that of presenting Japan to the world:

'At present, though, the English-speaking abilities of a large

percentage of the population are inadequate, and this imposes

restrictions on exchanges with foreigners and creates occasions

when the ideas and opinions of Japanese people are not

appropriately evaluated.'

(http://www.mext.go.jp/english/news/2002/07/020901.htm - 12th July 2002; cited in Byram, 2011 [link no longer exist])

The quotation indicates that it is important for the Japanese people to have a voice in the global community and this voice is in English. The English language is also linked to ability in the Japanese language:

'However, it is not possible to state that Japanese people have

sufficient ability to express their opinions based on a firm grasp of

their own language.

(http://www.mext.go.jp/english/news/2002/07/020901.htm - 12th July 2002; cited in Byram, 2011 [link no longer exist])

The implied meaning seems to be that the Japanese language should have priority over English, and that Japanese people should master Japanese first before learning English.

There is a tendency to see English as a threat to Japanese identity, and this tendency has been revealed at various times, such as in the debate about whether English should be taught in primary schools. Byram (2011) has shown with examples from Britain and Norway that the learning of another language need not be a threat to national identity. In fact, national identity can be strengthened in the context of foreign language learning:

'Language competence and intercultural understanding are an

essential part of being a citizen. Children develop a greater

understanding of their own lives in the context of exploring the lives

of others. They learn to look at things from another perspective.'

(Key Stage 2 Framework for Languages 2005; cited in Byram, 2011)

'By learning (foreign) languages, pupils have opportunity to

become familiar with other cultures. Such insight provides the basis

for respect and increased tolerance, and contributes to other ways

of thinking and broadens pupils' understanding of their own

cultural belonging. In this way pupils' own identity is strengthened.'

(http://www.utdanningsdirektoratet.no/dav78FB8D6918.PDF - January 2005; cited in Byram, 2011 [link no longer exist])

Language learning is linked to learning about other cultures which will have a positive effect on students' tolerance and understanding. Language teaching plays a role in the creation of national identity, in that learning about other people gives us a stronger sense of who we are.

In this study, the author found that the sakoku mentality has little influence on most of the respondents, although half of them felt that they had a choice in whether to be affected by globalisation or not. Most of them agreed on the importance and desirability of the ability to function in intercultural contexts, but half do not think they will be in 
these contexts. The majority perceived a real need for English and showed interest in being part of the global community.

The next section describes the study, followed by Section 3 in which the findings are presented and discussed. Section 4 concludes the paper.

\section{The Study}

109 students in four English classes that I taught participated in this study. The students were first or second year undergraduates from the faculties of Law, Engineering, Health Sciences and Agricultural Science. Nagoya University is a top national university and the students are thought to be academically-inclined. National university fees are lower than those of private universities and the students are from a variety of socioeconomic backgrounds.

The students were given a copy of a questionnaire developed by the author in class near the end of the semester. It was made very clear to them that participation was voluntary and the questionnaire had nothing to do with their grades in any way. The questionnaire was written in Japanese and consisted of 14 Likert-type statements such as 'It is important to be able to function in intercultural contexts' and 'I want to be able to function in intercultural contexts'. The respondents had to choose between the responses Strongly disagree, Disagree, Agree and Strongly agree. There was also space for comments for each statement.

\section{Findings and Discussion}

\subsection{Globalisation and Intercultural Contexts}

Most of the students (89\%) agreed that Japan was affected by globalisation and $81.7 \%$ felt it was untrue that staying in Japan meant they would not be reached by the forces of globalisation. There were no comments which reflected the sakoku mentality either. Based on the figures above, it seems that the sakoku mentality has little effect on the majority of the students.

However, half (52.3\%) thought that globalisation was a matter of choice and they could choose to be affected or not. The following comment from the earlier study (Morita, 2013) reflects this attitude:

'I, who want to be an English teacher, will teach internationalization

to future students, but personally it does not affect me at all.'

The above respondent made it clear that globalisation did not apply to him. It is something he would do at work but it means nothing to who he is. This contrasts sharply with descriptions of globalisation as unstoppable forces in the literature. None of the comments made clear the reason for thinking it was up to individuals to be affected by globalisation or not. There are probably multiple factors involved and they need further study.

The vast majority of the students (93.6\%) in the present study agreed that it was important to be able to function in intercultural contexts:

'Business overseas is becoming an important source of revenue'

'Since Japan lacks natural resources, we cannot maintain good

living standards like now unless we do business with foreign

countries.'

'I think it is important because the world is becoming

increasingly globalised.'

In the responses above, the first cited doing business with customers or companies outside Japan as an important source of income for Japanese businesses. The second also concerns profits from overseas business and in addition mentions Japan's lack of natural resources. The third cites the growing interconnectedness of the world. $62.4 \%$ wanted the ability to function in these contexts. However, half (52.3\%) did not think they would be in such contexts in future. The same pattern was found in the earlier study, a pattern of a high percentage (81.5\%) claiming it was important to be able to function in intercultural contexts, followed by a smaller number (53.7\%) wanting the ability 
and an even smaller number (50\%) thinking they would find themselves in these contexts. Globalisation and intercultural contexts seem to be abstract concepts and lack reality to the respondents in both studies. They know of the processes of globalisation and existence of intercultural contexts but they find it hard to picture themselves in them.

The author at first suspected that the students' inability to relate personally to globalisation and intercultural contexts was due to the lack of foreigners in their daily life, based on comments from students that they do not know any foreigners. She found that there were 67,322 foreigners in the city of Nagoya, or 3\% of the total population of 2,258,908, which is not a small number for the fourth largest city of Japan. (Office of the Mayor, City of Nagoya, 2010) The numbers of international students in the respondents' immediate environment, the university, were not low either. According to official university statistics, $16.5 \%$ or 1,611 of the undergraduate population of 9,783 are international. At Law, $20.1 \%$ or 138 of the 685 undergraduates are international; at Engineering, $10.5 \%$ or 359 of 3,405; at Agricultural Science, $7.7 \%$ or 57 of 741; and at Medicine and Health Sciences, $6.4 \%$ or 99 of 1,544. (Nagoya University, 2013)

Based on 10 years' teaching experience at the university, I would say a more likely explanation is the lack of contact or intercultural interaction with international students. The presence of international students does not necessarily mean that meaningful interaction takes place between them and Japanese students. International students at Nagoya University gain admission either via English or Japanese. Those who come in via English often take English-taught classes only where there are few or no Japanese students. The numbers of these international students are growing due to the G30 programme. The G30 project was launched by the government to increase the number of international students to 300,000 by the year 2020, mainly by opening English-medium courses and programmes. This project, in principle, enables Japanese universities to compete with universities in English-speaking countries for top international students, but in reality, segregates international students from domestic students and deprives both parties of invaluable opportunities for intercultural interaction. This explains why $76 \%$ of Japanese students at Nagoya University said there were few or no international students in their classes. (Morita, 2012) Opportunities for intercultural interaction outside the classroom were also few and far between. International students in English-taught programmes were very limited in their Japanese social circles. The only Japanese they interacted with were those who manned the help desk and those from a student organisation which provided support for international students.

\subsection{English}

84.4\% of the students in the present study perceived a real need for English communicative skills:

'To communicate in English is necessary to work in international

settings.'

'It is necessary once you start working.'

'You cannot do business abroad if you don't command a

minimum level of English.’

'English is the most effective communication tool in the

international world.’

'I think there will be more foreigners around in future.'

The responses indicate that English communicative skills are necessary in the workplace, especially intercultural workplace. One respondent feels that the number of foreigners in Japan will increase and English will be the language used between them and the Japanese. English is also rated as the most effective lingua franca in the world. 84.4\% is high given the mixed attitudes towards English in the Japanese context described in the Introduction. It is possible that the respondents are merely repeating government rhetoric. There are possibly differences between how students from different faculties feel about the need for English. In the earlier study (Morita, 2013) which surveyed students from Science, Literature and Engineering, comments which indicated that English was only useful for 
applying for jobs or taking entrance examinations were found:

'It is necessary just when I take an entrance exam for graduate

schools.'

Unfortunately, the student numbers from the respective faculties in the present study are not large enough for such analysis. These differences need to be studied in future research.

97.2\% felt they needed communicative skills in English if they wanted to function in intercultural contexts:

'I want to live in intercultural settings, in which case I need to be able

to communicate in English.'

'English is important if one lives in international settings.'

'A common language is necessary in intercultural contexts and

English is the one.'

90.8\% thought English was the most important international language:

'It is a lingua franca of the world, and one of the most important

means to communicate with foreigners.'

\subsection{Member of Global Community}

Most of the respondents (79.8\%) wanted to be part of the global community or something larger than Japan:

'If I have the appropriate abilities to be a member of the global

community, I want to be one.'

'Being inside Japan is not enough for me.'

There were a total of 42 comments on what being a member of the global community consisted of and they fell into three categories: English language skills (12, 28.6\%), knowing Japanese culture (12, 28.6\%) and a variety of others (18, 42.9\%) such as:

'To accept people and their culture.'

'To understand religious differences.'

'To have interests in many countries. Not to entertain discriminative

views.'

'Pay attention to international affairs regularly such as reading

newspapers and watching the news on TV.'

In addition to the 12 comments on the need for English skills in the global community ('I need English communication skills'), the lack of confidence in the use of English came up five times in relation to other questions in the data:

'I don't have any confidence in my English communication ability.'

This is clearly something which is on the mind of many students who are very concerned and needs to be addressed by educators and policy makers.

The most common method for teaching English in schools and universities is the grammar translation method, which had its origins in the beginning of the $20^{\text {th }}$ century, when the teaching of foreign languages focused on translation of written texts mainly for the purpose of keeping up with technological developments in the rest of the world and importing and processing information from foreign cultures. The main classroom activity in this method is systematic word-by-word translation of written English texts into Japanese. The teacher gives grammatical 
explanations in Japanese and English is hardly used. (Morita, 2010) This method is said to have harmful effects on language learning since the learning of authentic language is less valuable than the memorisation of language rules. (O’Donnell, 2003)

The need for a more communicative-based approach has been a constant refrain over the last 30 years. (Seargeant, 2009) The government attempted to improve English language education in the Reform Acts of 1989 and 2002, which emphasised a communicative approach to English language teaching. In the last few decades, the grammar translation method has been challenged to some degree by communicative approaches which are common in the field of Teaching English as a Second Language (TESOL) in the West. (Seargeant, 2011) Other improvements include the establishment of the Japan Exchange and Teaching (JET) programme in 1987 which invites native speakers of English to work as assistant English teachers in schools. In 1997, English conversation was introduced in elementary schools as an elective. From 2006, the central university entrance examination included a listening component. In spite of the improvements, the grammar translation approach is still common in schools and universities. (Nishino, 2008; Stewart \& Miyahara, 2011)

Learners' motivation is an important factor in language learning. Research has shown that Japanese undergraduates' motivation to learn English is low in general (Hayashi, 2005) and that the grammar translation method and entrance examinations have negative effects on motivation. (Kikuchi \& Sakai, 2009)

In addition to eroding students' motivation, the grammar translation method has been inadequate in equipping students with necessary English skills. Japan has historically scored very low among Asian nations' mean scores in the Test of English as a Foreign Language (TOEFL) score rankings. (Morita, 2010) In a recent test and score data summary for the TOEFL Internet-based and paper-based tests, Japan continues to lag behind (Educational Testing Service, 2009). In as recent as 2011, Yano described the Japanese as hardly having enough English proficiency to successfully conduct business negotiations, academic presentations and discussions.

If educators are serious about preparing students for intercultural contexts in future, they need to modify their teaching methods to give students knowledge and abilities to function in such an environment. Where English is concerned, it means teaching students to communicate effectively across cultures. The ability to communicate effectively has been a well-established goal in English Language Teaching (ELT). (Hedge, 2000)

In the literature on learners' motivation to learn a second language, the teacher's teaching methods play an important role. (Dornyei, 2001) One of the shortcomings of the grammar translation method is the limitation to grammar and lexical knowledge, which is part of a more traditional approach in ELT. In order to communicate effectively across cultures, students also need the ability to make use of linguistic and other communicative resources in the negotiation of meaning, roles and relationships in the diverse sociocultural settings of intercultural communication through English.

12 responses focused on one's culture in the context of being a member of the global community:

'I should understand Japanese culture well, and I should be careful not to lose sight of the goodness Japan originally had

because of too much globalization.’

'Introduce our country and culture to other countries. In

order to do that, one should have enough knowledge about

his or her country’s history.'

'I need to understand my own country’s culture, Japanese culture,

in order to join the global community.'

'To learn different cultures. More importantly, to know more

about one's own country.'

The first comment is a warning about forgetting Japanese culture due to excessive globalisation. In other words, globalisation is a threat to the national culture. The second, third and fourth emphasise giving priority to Japanese 
culture. The national culture should come first before one presents Japan to the rest of the world, learn about other cultures or become a member of the global community. The focus on one's culture in understanding membership of a global community may come as a surprise but not so in the context of Japan. Hashimoto (2009) has shown that Japanese understandings of international education or internationalisation promote such a view. The views stated are similar to government policy aims.

In a study on a related theme, Parmenter (2011) surveyed 642 university students worldwide on their conceptualisations of global citizenship. The students were asked to define a global citizen in their own words in the questionnaire. The four core concepts which emerged as being integral to global citizenship were human-beingness, connectedness, engagement, and transformation. It is interesting that none of them are related to the emphasis on one's culture found in the present study, which is possibly unique to Japan.

This focus on Japanese culture in the context of being part of the global community mirrors a complexity Hashimoto (2009) found in her analysis of government documents. She argues convincingly that what the government claims to promote can be quite different from what it really wants to achieve. Although Japan embraced internationalistion, there was at the same time an emphasis on the importance of Japanese culture and tradition. The focus was on the exportability of Japanese culture to the world or the promotion of Japaneseness in the international community. Likewise in the discourse on the teaching of English, emphasising the importance of Japanese culture is routine practice for educational policy makers. The learning of English as a lingua franca to increase global literacy should be carried out within the framework of Japanese culture. The goal is the enrichment of Japanese language and culture through interaction with other cultures and languages. In the present study, the effect of government rhetoric is clear. The question on what a member of the global community needs to do prompted the respondents to be protective of Japanese culture.

\section{Conclusion}

We have seen in this paper that, with only a couple of exceptions, students' attitudes echo government rhetoric. They believe that the forces of globalisation are sweeping through Japan, that it is desirable to be able to function in intercultural contexts, that English communicative skills are indispensable in their future, and that it is more important to know Japanese culture before one participates in the global community. Most of the respondents show interest in integrating with the international community. However, the fact that they think they have a choice in whether they want to be affected by globalisation needs to be studied. In addition, the lack of reality of intercultural contexts needs to be addressed. This is possibly related to what Burgess (2013) describes as something rooted in an insular world view that sees globalisation as an external process, something owned by somebody else.

A recent editorial in the Japan Times reported on the findings of a survey related to the present study. $50 \%$ of high school students and 55\% of university students said they felt it was too late for them to become globally active. The author claims that students pick up the attitude from their environment, namely, their parents, teachers, media and society. $40 \%$ of high school students and $30 \%$ of university students said they wanted to become an active person in a global society but did not know how to do it. The responsibility falls on the government, businesses, educators and parents to guide young people.

In the literature on the internationalisation of higher education, the recommended teaching objectives are usually based on the assumption that students will find themselves in intercultural contexts. In that case, higher education will be more effective if students share this vision about the future. One way to improve the reality of intercultural contexts is to start a course on intercultural communication in which both Japanese and international students can earn credits. This will be a good setting for intercultural communication since both parties will be motivated to participate. The trained and/or experienced lecturer acts as a mediator and at the same time offers support for Japanese students' efforts to communicate in English. Both parties will benefit tremendously from the interaction, which prepares them for their future work and living environment. Such a course would be more consistent with internationalisation rather than the university's recent emphasis on academic writing and Computer Assisted Language Learning (CALL) which excludes the communicative aspects most of the time. If students' participation in the global community is conditional upon their English communication skills as they suggested in this study, then it is a matter of great priority and urgency to equip them with these skills 


\section{References}

Burgess, C. (2013, May 21). Ambivalent Japan turns on its 'insular' youth: System discourages overseas study but students get blame. The Japan Times. http://www.japantimes.co.jp/community/2013/05/21/issues/ambivalent-japan-turns-on-its-insular-youth/

Byram, M. (2011). From foreign language education to education for intercultural citizenship. Intercultural Communication Review, 9, 17-35.

Clammer, J. (2001). In but not of the world? Japan, globalization and the 'end of history'. In C. Hay \& D. Marsh (Eds.), Demystifying globalization (pp. 147-167). Basingstoke: Palgrave.

Dornyei, Z. (2001). Teaching and researching motivation. Harlow: Longman.

Dougill, J. (1995). Internationalization—as if it mattered. In K. Kitao (Ed.), Culture and communication (pp. 61-73). Kyoto: Yamaguchi Shoten.

Educational Testing Service. (2009). Test and score data summary for TOEFL internet-based and paper-based tests. Princeton: Educational Testing Service.

Featherstone, M. (1990). Global culture: An introduction. In M. Featherstone (Ed.), Global culture: nationalism, globalization and modernity: A theory, culture \& society special issue (pp. 1-14). London: Sage

Gottlieb, N. (2005). Language and society in Japan. Cambridge: Cambridge University Press. http://dx.doi.org/10.1017/CBO9780511614248

Hashimoto, K. (2009). Cultivating “Japanese who can use English”: Problems and contradictions in government policy. Asian Studies Review, 33, 21-42. http://dx.doi.org/10.1080/10357820802716166

Hayashi, H. (2005). Identifying different motivational transitions of Japanese ESL learners using cluster analysis: Self-determination perspectives. JACET Bulletin, 41, 1-17.

Hedge, T. (2000). Teaching and learning in the language classroom. Oxford: Oxford University Press.

Heyward, M. (2002). From international to intercultural: Redefining the international school for a globalized world. Journal of Research in International Education, 1(1), 9-32.

Hudzik, J. K. (2011). Comprehensive internationalization. Washington, D.C.: NAFSA.

Itoh, M. (2000). Globalization of Japan: Japanese sakoku mentality and U.S. efforts to open Japan. Basingstoke: Macmillan.

Kikuchi, K., \& Sakai, H. (2009). Japanese learners' demotivation to study English: A survey study. JALT Journal, 31(2), 183-204.

Knight, J. (1999). Internationalisation of higher education. In OECD, Quality and internationalisation in higher education (pp. 13-28). Paris: OECD.

Kubota, R. (2011). Immigration, diversity and language education in Japan: Toward a glocal approach to teaching English. In P. Seargeant (Ed.), English in Japan in the era of globalization (pp. 101-122). Basingstoke: Palgrave Macmillan.

Marginson, S. (2003). Markets in higher education: National and global competition. Paper presented at the NZARE/AARE Joint Conference.

Matsuda, A. (2011). 'Not everyone can be a star': Students' and teachers' beliefs about English teaching in Japan. In P. Seargeant (Ed.), English in Japan in the era of globalization (pp.38-59). Basingstoke: Palgrave Macmillan.

MEXT. (2002). Towards advancement of "academic ability": Increased efforts for the secure improvement of "academic ability: Efforts by the Ministry of Education, Culture, Sports, Science and Technology. Retrieved July 23, 2012, from http://www.mext.go.jp/b_menu/hakusho/html/hpac200201/hpac200201_2_015.html

Morita, L. (2010). The sociolinguistic context of English education in Japan and Singapore. Electronic Journal of Contemporary Japanese Studies. http://www.japanesestudies.org.uk/discussionpapers/2010/Morita.html

Morita, L. (2012). English and intercultural interaction in the internationalisation of a Japanese university. Journal of Intercultural Communication, 30. http://www.immi.se/intercultural

Morita, L. (2013). Globalisation, intercultural contexts and the sociocultural component of an English course. Journal of English as an International Language, 8(1), 55-68. 
Nagoya University. Retrieved February 22, 2013, from http://www.nagoya-u.ac.jp/about-nu/history-data/figure/

Nishino, T. (2008). Japanese secondary school teachers' beliefs and practices regarding communicative language teaching: An exploratory survey. JALT Journal, 30(1), 27-50.

O’Donnell, K. (2003). Uncovering first year students' language learning experiences, attitudes, and motivations in a context of change at the tertiary level of education. JALT Journal, 25(1), 31-62.

Office of the Mayor, City of Nagoya. (2010). Nagoya Foreign Residents Survey Results Announcement. Retrieved February 22, 2013, from http://www.city.nagoya.jp/en/cmsfiles/contents/0000023/23403/english.pdf

Parmenter, L. (2011). Power and place in the discourse of global citizenship education. Globalisation, Education and Societies, 9(3-4), 367-380. http://dx.doi.org/10.1080/14767724.2011.605322

Seargeant, P. (2009). The idea of English in Japan: Ideology and the evolution of a global language. Bristol: Multilingual Matters.

Seargeant, P. (2011). Introduction: English in Japan in the era of globalization. In P. Seargeant (Ed.), English in Japan in the era of globalization (pp. 1-12). Basingstoke: Palgrave Macmillan. http://dx.doi.org/10.1057/9780230306196

Stewart, A., \& Miyahara, M. (2011). Parallel universes: Globalization and identity in English language teaching at a Japanese university. In P. Seargeant (Ed.), English in Japan in the era of globalization (pp. 60-79). Basingstoke: Palgrave Macmillan.

Stiglitz, J. (2002). Globalization and its discontents. New York: W.W. Norton.

The Japan Times. (2013, June 16). Too many inward-looking students. http://www.japantimes.co.jp/opinion/2013/06/16/editorials/too-many-inward-looking-students/

Tsuchiya, M. (2004). Factors in demotivation concerning learning English: A preliminary study of Japanese university students. The Kyushu Academic Society of English Language Education (KASELE), 32, 39-46.

Turner, Y., \& Robson, S. (2008). Internationalizing the university. London: Continuum.

Weber, S. (Ed.). (2001). Globalization and the European political economy. New York: Columbia University Press.

Whitsed, C., \& Wright, P. (2011). Perspectives from within: Adjunct, foreign, English-language teachers in the internationalization of Japanese universities. Journal of Research in International Education, 10(1), 28-45. http://dx.doi.org/10.1177/1475240910396332

Yamagami, M., \& Tollefson, J. W. (2011). Elite Discourses of Globalization in Japan: the Role of English. In P. Seargeant (Ed.), English in Japan in the era of globalization (pp. 15-37). Basingstoke: Palgrave Macmillan.

Yano, Y. (2001). World Englishes in 2001 and beyond. World Englishes, 20(2), 119-131. http://dx.doi.org/10.1111/1467-971X.00204

Yano, Y. (2011). English as an international language and 'Japanese English'. In P. Seargeant (Ed.), English in Japan in the era of globalization (pp. 125-142). Basingstoke: Palgrave Macmillan. 